\title{
The Isoporpylation of Biphenyl over H-Mordenites. Roles of External Surface in Shape-Selective Catalysis
}

\author{
Shogo TAwAdA *1, Yoshihiro KuBOTA*1, Yoshihiro SugI*1, Yoshimichi KIYOZUmI*2, \\ Taka-aki HANAOKA*2, and Fujio MizUKAMI*2
}

(Received June 11, 2004)

\begin{abstract}
Influences of external surface and total areas of some H-mordenites (HM) were examined to elucidate the role of external acid sites in the isopropylation of biphenyl (BP).

The several types of $\mathrm{HM}\left(\mathrm{SiO}_{2} / \mathrm{Al}_{2} \mathrm{O}_{3}\right.$ ratio: 12-19; $\mathrm{BET}$ surface area $480-500 \mathrm{~m}^{2} / \mathrm{g}$; external surface area: $0.1-25 \mathrm{~m}^{2} / \mathrm{g}$ ) were obtained commercially or synthesized by the methods referred to the literature for ZSM-5 and other zeolites. The selectivity for 4,4' -diisopropylbiphenyl (4,4' -DIPB) was almost constant for all HMs in the isopropylation; however, the catalytic activity was varied by samples.

H-Mordenites with different particle size $\mathrm{HM}[\mathrm{a}]$ (average particle size $2 \mu \mathrm{m} ; \mathrm{SiO}_{2} / \mathrm{Al}_{2} \mathrm{O}_{3}=18.7$; external surface area: $17 \mathrm{~m}^{2} / \mathrm{g}$ ) and $\mathrm{HM}[\mathrm{b}]$ (average particle size $1 \mu \mathrm{m} ; \mathrm{SiO}_{2} / \mathrm{Al}_{2} \mathrm{O}_{3}=15.7$; external surface area: $25 \mathrm{~m}^{2} / \mathrm{g}$ ) were dealuminated by the combination of steam treatment at $600{ }^{\circ} \mathrm{C}$ and acid leaching at $80{ }^{\circ} \mathrm{C}$. The selectivity for 4,4' -DIPB was in the similar level for both series of $\mathrm{HMs}$ in the range of $\mathrm{SiO}_{2} / \mathrm{Al}_{2} \mathrm{O}_{3}$ ratio from 20 to 400. However, the catalytic activity was varied with the ratio.

These results from two types of HMs show that selective formation of 4,4'-DIPB occurred inside the pores of HMs, that the external acid sites did not play an important role on the shape-selectivity, and that catalytic activities for the isopropylation were influenced by external surface area.
\end{abstract}

\section{Key Words}

H-mordenite, External acid sites, Shape-selective catalysis, Biphenyl, Isopropylation

\section{Introduction}

Polynuclear aromatics in coal tar or in liquefied coal, such as naphthalene and biphenyl, are valuable components for chemical use. It is important to develop the utilization of these aromatics for advanced materials, such as liquid crystals, heat-resistant and liquid crystalline polymers. Shapeselective catalysis using zeolites is one of promisable methods for their functionalization. H-Mordenite (HM) is a highly active catalyst to yield the slimmest products in the isopropylation of biphenyl (BP) at moderate temperatures ${ }^{1)}$

* 1 Department of Materials Science and Technology, Faculty of Engineering, Gifu University 1-1, Yanagito, Gifu, Gifu 501-1193, Japan

* 2 Laboratory for Membrane Chemistry, Advanced National Institute of Science and Technology 4-2-1, Nigatake, Miyagino-ku, Sendai, Miyagi 983-8551, Japan
ح). We proposed the catalysis occurs inside the pores of $\mathrm{H}^{-}$ mordenite (HM) by restricted transition state mechanism ${ }^{11}$ $\sim 5)$. However, the decrease of the selectivity of $4,4^{\prime}-$ diisopropylbiphenyl (4,4' -DIPB) was observed at high temperatures or under low propylene pressure ${ }^{344}$. The decrease of the selectivity occurs on external acid sites by the isomerization of 4,4' -DIPB formed inside the pores by shape-selective catalysis ${ }^{13} \sim 5$. However, the role of external acid sites is still unclear at moderate temperatures.

Particle sizes and external surface area of zeolites, which are closely related to amounts of external acid sites, can be changed by the preparation methods in zeolites ${ }^{\text {Th }}{ }^{2}$. In this paper, we examined the isopropylation of BP over HMs with different external surface area to elucidate the roles of external surface area on the catalysis. 


\section{Experimental}

\subsection{H-Mordenites}

H-Mordenites (HM, $\mathrm{SiO}_{2} / \mathrm{Al}_{2} \mathrm{O}_{3}=18.7$ (HM[a]); 15.7 (HM

[b]); 128 (HM(128)) were supplied from Tosoh Corporation Inc. Tokyo, Japan. The dealumination of HMs was carried out by two methods: 1) steam treatment of HM[a] and HM [b] at $600{ }^{\circ} \mathrm{C}$. 2) Acid leaching of aluminum oxide at $80{ }^{\circ} \mathrm{C}$ with hydrochloric or nitric acid solution. HMs with different $\mathrm{SiO}_{2} / \mathrm{Al}_{2} \mathrm{O}_{3}$ ratio were obtained by the combination of two methods and types of acid.

Syntheses of HMs with different particle size were carried out by changing the gel compositions and synthetic conditions referred to the literatures ${ }^{\text {?) }}{ }^{12}$ ) for H-ZSM- 5 or other zeolites. Before use, all samples were calcined under a flow of air $\left(100 \mathrm{ml} \cdot \mathrm{min}^{-1}\right)$ by raising temperature at a rate of $2{ }^{\circ} \mathrm{C} \cdot \mathrm{min}^{-1}$, and keeping the temperature at $550{ }^{\circ} \mathrm{C}$ for $7 \mathrm{~h}$ in a muffle furnace. Detailed synthetic procedures for HM[c] $\sim \mathrm{HM}[\mathrm{h}]$ are given below.

HM[c]: To a solution of $\mathrm{NaOH}(1.91 \mathrm{~g}, 47.7 \mathrm{mmol})$ in deionized water $(26.2 \mathrm{~g}), 1.27 \mathrm{~g}$ of sodium aluminate (Nacalai Tesque, $42.8 \% \mathrm{SiO}_{2} / \mathrm{Al}_{2} \mathrm{O}_{3}, 33.7 \% \mathrm{Na}_{2} \mathrm{O}$ ) was added, and stirred for $10 \mathrm{~min}$. To this mixture, $31.6 \mathrm{~g}(160 \mathrm{mmol})$ of colloidal silica (Cataloid SI-30, Catal. Chem. Co. Ltd., $\mathrm{SiO}_{2}, 30.4 \%$; $\mathrm{Na}_{2} \mathrm{O}$, $0.043 \%)$ was added with stirring. The stirring was continued for $10 \mathrm{~min}$. Finally, $192 \mathrm{mg}$ of seed crystals (preliminarily prepared following the same procedure without adding seeds) were added, and the whole mixture was further stirred for $30 \mathrm{~min}$. Final composition was $1.0 \mathrm{SiO}_{2}{ }^{-}$ $0.387 \mathrm{NaOH}-0.033 \mathrm{Al}_{2} \mathrm{O}_{3}-26 \mathrm{H}_{2} \mathrm{O}$. The mixture was then transferred to Teflon-lined autoclave $(125 \mathrm{ml})$, and heated statically in a convection oven at $175{ }^{\circ} \mathrm{C}$ for $24 \mathrm{~h}$. As-synthesized product $(6.44 \mathrm{~g})$ was recovered by filtration, washing with de-ionized water, and drying at room temperature.

HM[d]: To a solution of $\mathrm{NaOH}(1.91 \mathrm{~g}, 45.8 \mathrm{mmol})$ in deionized water $(52.8 \mathrm{~g}), 1.27 \mathrm{~g}$ of sodium aluminate (Nacalai Tesque, $42.8 \% \mathrm{Al}_{2} \mathrm{O}_{3}, 33.7 \% \mathrm{Na}_{2} \mathrm{O}$ ) was added and stirred for $10 \mathrm{~min}$. To this mixture, $31.6 \mathrm{~g}$ (160 mmol) of colloidal silica (Cataloid SI-30) was added with stirring. The stirring was continued for $10 \mathrm{~min}$. Finally, $192 \mathrm{mg}$ of seed crystals were added, and the whole mixture was further stirred for 40 min. Final composition was $1.0 \mathrm{SiO}_{2}-0.375 \mathrm{NaOH}-0.033 \mathrm{Al}_{2} \mathrm{O}_{3}{ }^{-}$ $26 \mathrm{H}_{2} \mathrm{O}$. After treating in an ultrasound bath $(50 \mathrm{~W}, 40 \mathrm{kHz})$ for $6 \mathrm{~h}$, the mixture was then transferred to Teflon-lined autoclave (125 ml), and heated statically in a convection oven at $175{ }^{\circ} \mathrm{C}$ for $24 \mathrm{~h}$. As-synthesized product (7.45 g) was recovered by filtration, washing with de-ionized water, and drying at room temperature.

HM[e]: To a solution of $\mathrm{NaOH}(2.92 \mathrm{~g}, 72.9 \mathrm{mmol})$ in 49.4 $\mathrm{g}$ of de-ionized water, $1.19 \mathrm{~g}$ of sodium aluminate (Nacalai Tesque, $42.8 \% \mathrm{Al}_{2} \mathrm{O}_{3}, 33.7 \% \mathrm{Na}_{2} \mathrm{O}$ ) was added, and stirred for
$10 \mathrm{~min}$. To this mixture, $398 \mathrm{mg}(2.14 \mathrm{mmol})$ of benzyltrimethylammonium chloride (BTMACl) was added, and the stirring was continued for $10 \mathrm{~min}$. Finally, $29.645 \mathrm{~g}$ (150 mmol) of colloidal silica (Cataloid SI-30) was added with stirring, and whole mixture was further stirred for 30 min. Final composition was $1.0 \mathrm{SiO}_{2}-0.575 \mathrm{NaOH}-0.033 \mathrm{Al}_{2} \mathrm{O}_{3}-$ $0.014 \mathrm{BTMACl}-26 \mathrm{H}_{2} \mathrm{O}$. After treating in an ultrasound bath ( $50 \mathrm{~W}, 40 \mathrm{kHz}$ ) for $1 \mathrm{~h}$, the mixture was then transferred to Teflon-lined autoclave $(125 \mathrm{ml})$, and heated statically in a convection oven at $175{ }^{\circ} \mathrm{C}$ for $72 \mathrm{~h}$. As-synthesized product $(4.79 \mathrm{~g})$ was recovered by the filtration, washing with de-ionized water, and drying at room temperature.

HM[f]: To a solution of $\mathrm{NaOH}(2.95 \mathrm{~g}, 73.8 \mathrm{mmol}$ ) in 49.6 $\mathrm{g}$ of de-ionized water, $1.19 \mathrm{~g}$ of sodium aluminate (Nacalai Tesque, $42.8 \% \mathrm{Al}_{2} \mathrm{O}_{3}, 33.7 \% \mathrm{Na}_{2} \mathrm{O}$ ) was added, and stirred for $10 \mathrm{~min}$. To this mixture, $401 \mathrm{mg}(2.16 \mathrm{mmol})$ of BTMACl was added, and the stirring was continued for $10 \mathrm{~min}$. Finally, $29.78 \mathrm{~g}$ (151 mmol) of colloidal silica (Cataloid SI-30) was added with stirring, and the whole mixture was further stirred for $3 \mathrm{~h}$. Final composition was $1.0 \mathrm{SiO}_{2}$ $0.578 \mathrm{NaOH}-0.033 \mathrm{Al}_{2} \mathrm{O}_{3}-0.014 \mathrm{BTMACl}-26 \mathrm{H}_{2} \mathrm{O}$. The mixture was then transferred to Teflon-lined autoclave (125 ml), and heated statically in a convection oven at $175{ }^{\circ} \mathrm{C}$ for 72 h. As-synthesized product ( $4.42 \mathrm{~g}$ ) was recovered by the filtration, washing with de-ionized water, and drying at room temperature.

HM[g]: To a solution of $\mathrm{NaOH}(2.98 \mathrm{~g}, 74.5 \mathrm{mmol})$ in 49.5 $\mathrm{g}$ of de-ionized water, $1.19 \mathrm{~g}$ of sodium aluminate (Nacalai Tesque, $42.8 \% \mathrm{Al}_{2} \mathrm{O}_{3}, 33.7 \% \mathrm{Na}_{2} \mathrm{O}$ ) was added, and stirred for $10 \mathrm{~min}$. To this mixture, $399 \mathrm{mg}(2.15 \mathrm{mmol})$ of BTMACl was added, and the stirring was continued for $10 \mathrm{~min}$. Finally, $29.70 \mathrm{~g}(150 \mathrm{mmol})$ of colloidal silica (Cataloid SI-30) was added with stirring, and whole mixture was further stirred for $3 \mathrm{~h}$. Final composition was $1.0 \mathrm{SiO}_{2}-0.541 \mathrm{NaOH}-$ $0.033 \mathrm{Al}_{2} \mathrm{O}_{3}-0.014 \mathrm{BTMACl}-26 \mathrm{H}_{2} \mathrm{O}$. After treating in an ultrasound bath (50 W, $40 \mathrm{kHz}$ ) for $1 \mathrm{~h}$, the mixture was then transferred to Teflon-lined autoclave $(125 \mathrm{ml})$, and heated in a convection oven at $175{ }^{\circ} \mathrm{C}$ for $72 \mathrm{~h}$ with rotation (40 rpm). As-synthesized product ( $5.23 \mathrm{~g}$ ) was recovered by the filtration, washing with de-ionized water, and drying at room temperature.

HM[h]: To a solution of $\mathrm{NaOH}(2.91 \mathrm{~g}, 72.9 \mathrm{mmol})$ in 49.4 $\mathrm{g}$ of de-ionized water, $1.20 \mathrm{~g}$ of sodium aluminate (Nacalai Tesque, $42.8 \% \mathrm{Al}_{2} \mathrm{O}_{3}, 33.7 \% \mathrm{Na}_{2} \mathrm{O}$ ) was added, and stirred for $10 \mathrm{~min}$. To this mixture, $395 \mathrm{mg}(2.13 \mathrm{mmol})$ of BTMACl was added, and the stirring was continued for $10 \mathrm{~min}$. Finally, $29.7 \mathrm{~g}$ (150 mmol) of colloidal silica (Cataloid SI-30) was added with stirring, and whole mixture was further stirred for $3 \mathrm{~h}$. Final composition was $1.0 \mathrm{SiO}_{2}-0.574 \mathrm{NaOH}^{-}$ $0.033 \mathrm{Al}_{2} \mathrm{O}_{3}-0.014 \mathrm{BTMACl}-26 \mathrm{H}_{2} \mathrm{O}$. The mixture was then 
transferred to Teflon-lined autoclave $(125 \mathrm{ml})$, and heated in a convection oven at $175{ }^{\circ} \mathrm{C}$ for $72 \mathrm{~h}$ with rotation (40 rpm). As-synthesized product (5.48 g) was recovered by the filtration, washing with de-ionized water, and drying at room temperature.

After calcination of as-synthesized samples at $550{ }^{\circ} \mathrm{C}, \mathrm{H}^{-}$ mordenites $\mathrm{HM}[\mathrm{c}]-\mathrm{HM}[\mathrm{h}]$ were obtained by ion-exchange with $1 \mathrm{~N}$ ammonium nitrate solution, and followed by calcination at $550{ }^{\circ} \mathrm{C}$ for $5 \mathrm{~h}$.

\subsection{Characterization}

Phase purity and crystallinity of as-synthesized samples were determined by powder X-ray diffraction (XRD) (XRD6000, Shimadzu Corporation, Kyoto, Japan) with Cu K $\alpha$ radiation $(\lambda=1.5418 \AA$ ). Crystal size and morphology were determined by scanning electron microscopy (SEM; Philips XL30). Elemental analyses were performed by inductively coupled plasma atomic emission spectroscopy (ICP-AES; JICP-PS-1000 UV by Leeman Labs Inc., Tokyo, Japan). Nitrogen adsorption measurements were carried on a Belsorp 28SA (Bel Japan, Osaka, Japan) apparatus.

External surface area was determined out by $t$-plot method based on nitrogen adsorption isotherm of $\mathrm{HMs}^{13}$.

\subsection{Isopropylation}

The isopropylation of BP was carried out in a 100-ml SUS-316 autoclave under propylene pressure. Typical conditions were: $100 \mathrm{mmol}$ of $\mathrm{BP}, 0.5 \mathrm{~g}$ of catalyst, $0.8 \mathrm{MPa}$ of propylene pressure, $250{ }^{\circ} \mathrm{C}$ of temperature, and $4 \mathrm{~h}$ of period. $\mathrm{BP}$ and $\mathrm{HM}$ were introduced to an autoclave, and the autoclave was purged with nitrogen before heating. After reaching reaction temperature, $0.8 \mathrm{MPa}$ of propylene was introduced to the autoclave, and the reaction was started with agitation. The pressure kept constant throughout the reaction. After cooling the autoclave, the catalysts were filtered off, and bulk products were diluted with toluene. The products were analyzed by a Gas Chromatograph (Shimadzu GC-14A) equipped with an Ultra-1 capillary column ( $25 \mathrm{~m} \times 0.2 \mathrm{~mm}$ ), and identified by a Gas Chromatograph-Mass Spectrometer (Shimadzu GC-MS 5000).

The analysis of encapsulated products in the catalyst used for the reaction was carried out as follows. The catalyst was filtered off, washed well with $200 \mathrm{ml}$ of acetone, and dried at $110{ }^{\circ} \mathrm{C}$ for 12 h. $300 \mathrm{mg}$ of resulting catalyst. was carefully dissolved using $3 \mathrm{ml}$ of aqueous hydrofluoric acid (47\%) at room temperature. This solution was basified with solid potassium carbonate, and organic layer was extracted three times with $20 \mathrm{ml}$ of dichloromethane. After removal of the solvent in vacuo, the residue was dissolved in $5 \mathrm{ml}$ of toluene. GC analysis was done according to the same procedure for bulk products.

The yield of each product is calculated on the basis of the initial amount of BP, and the selectivities for each isopropylbiphenyl (IPBP) and diisopropylbiphenyl (DIPB) isomers are expressed based on total amount of IPBP and DIPB isomers, respectively.

\section{Results and Discussion}

\subsection{Properties of $\mathrm{H}$-mordenites}

$\mathrm{H}$-mordenites in this study were obtained from Tosoh Corporation (HM[a], $\mathrm{HM}[\mathrm{b}]$, and $\mathrm{HM}(128)$ ) and by the synthesis of $\mathrm{HM}[\mathrm{c}] \sim \mathrm{HM}[\mathrm{h}]$ described in the experimental section. XRD patterns and SEM images of typical samples are shown in Figs. 1 and 2. They give the similar XRD patterns; however, the morphologies are different for all HMs. The discussion based on particle size seems inappropriate be-
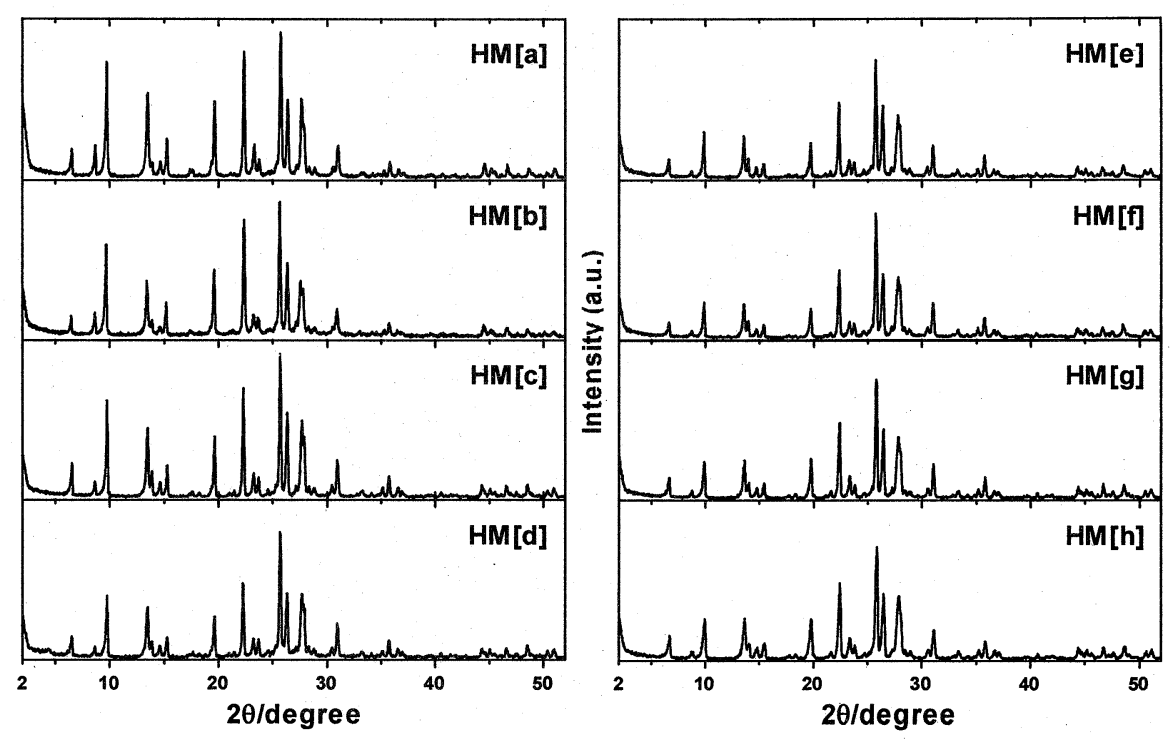

Fig. 1 XRD patterns of $\mathrm{H}$-mordenites 

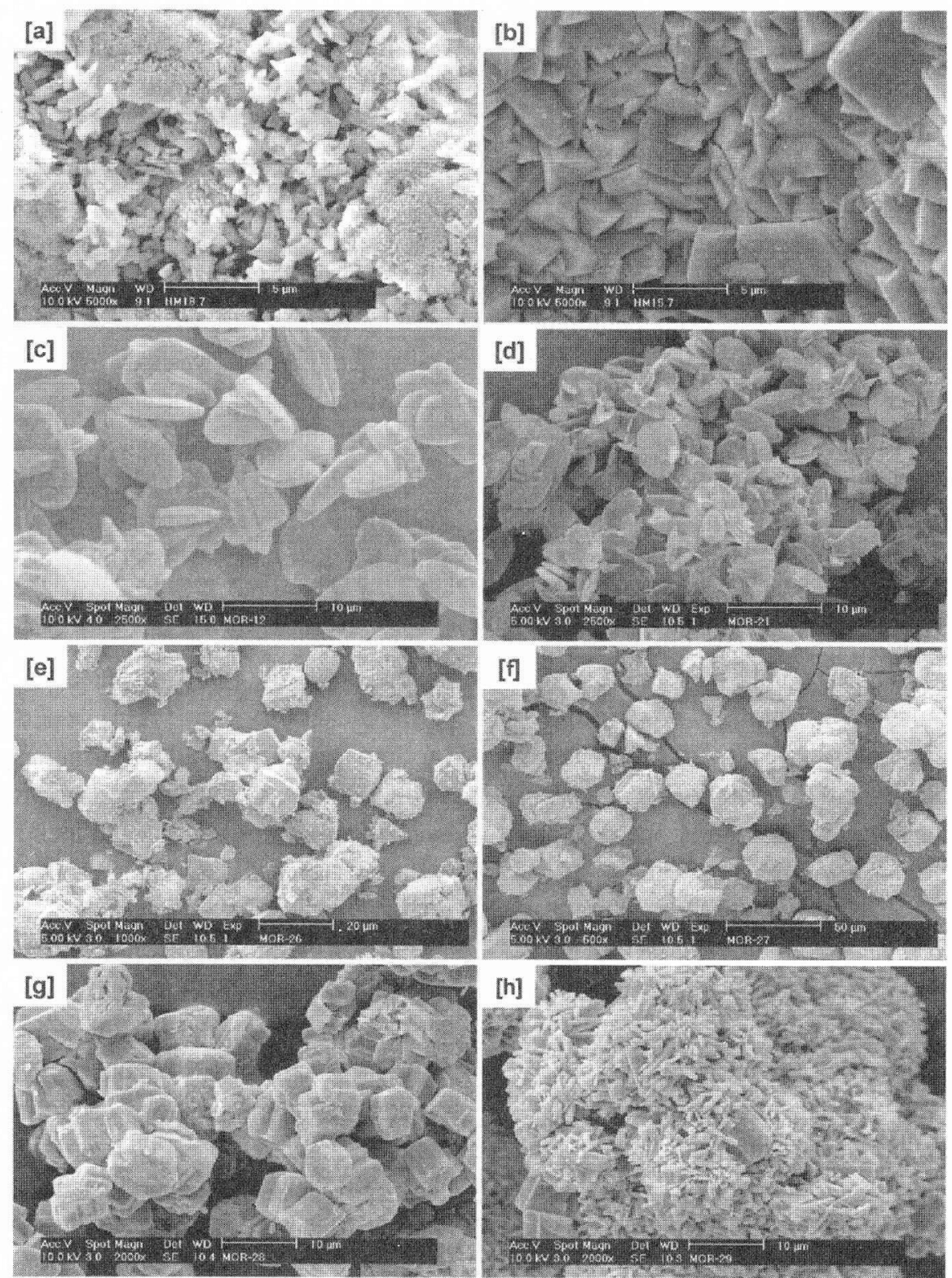

Fig. 2 SEM images of $\mathrm{H}$-mordenites

cause of their wide variation of morphologies, and therefore, we discuss the roles of external acid sites on the basis of external surface area of HMs in the isopropylation of polynuclear aromatics.

Table 1 shows properties of HMs. They have the surface area from 480 to $560 \mathrm{~m}^{2} / \mathrm{g}$, and their $\mathrm{SiO}_{2} / \mathrm{Al}_{2} \mathrm{O}_{3}$ ratios are in the range of 12.8-18.7. Pore volumes of HMs are in the similar level among the samples. External surface area measured by $t$-plot method was changed from 5 to $25 \mathrm{~m}^{2} / \mathrm{g}$ : they are due to the difference of morphology.

Kiyozumi and his co-workers found that the small particle size of ZSM-5 zeolites could be obtained by the ultrasonic radiation during the synthesis ${ }^{111}$. We obtained HMs with different external surface area with similar $\mathrm{SiO}_{2} / \mathrm{Al}_{2} \mathrm{O}_{3}$ ratio following by literatures although particle size was not changed significantly and no particular relation on morphologies were found by the method.

Table 2 summarizes the properties of dealuminated HMs in two series HM[a] and HM[b]: which have different morphologies and particle sizes. Their surface areas are 506$560 \mathrm{~m}^{2} / \mathrm{g}$, and their particle sizes were around 1.0 and 2.5 $\mu \mathrm{m}$, respectively. Their external surface areas were 25.3 and $17.2 \mathrm{~m}^{2} / \mathrm{g}$, respectively. The dealumination was carried out by methods as shown in experimental section. The surface areas of resulting HMs were not changed so much by the dealumination as shown in Fig. 3. 
Table 1 Properties of $\mathrm{H}$-mordenites

\begin{tabular}{|c|c|c|c|c|c|}
\hline Sample & $\mathrm{SiO}_{2} / \mathrm{Al}_{2} \mathrm{O}_{2}$ & \begin{tabular}{|c|}
$\begin{array}{c}\text { Surface area } \\
\left(\mathrm{m}^{2} / \mathrm{g}\right)\end{array}$ \\
\end{tabular} & \begin{tabular}{|c|}
$\begin{array}{c}\text { Pore volume } \\
\left(\mathrm{mm}^{3} / \mathrm{g}\right)\end{array}$ \\
\end{tabular} & $\begin{array}{c}\text { External } \\
\left(\mathrm{m}^{2} / \mathrm{g}\right)\end{array}$ & $\frac{\text { Surface area }}{(\%)^{a}}$ \\
\hline $\mathrm{HM}[\mathrm{a}]$ & 18.7 & 504.5 & 198.5 & 25.3 & 5.1 \\
\hline $\mathrm{HM}[\mathrm{b}]$ & 15.7 & 562.4 & 222.1 & 17.2 & 3.1 \\
\hline $\mathrm{HM}[\mathrm{c}]$ & 15.4 & 529.5 & 209.3 & 18.3 & 3.5 \\
\hline $\mathrm{HM}[\mathrm{d}]$ & 15.8 & 476.9 & 189.6 & 13.2 & 2.8 \\
\hline $\mathrm{HM}[\mathrm{e}]$ & 12.4 & 496.1 & 211.8 & 7.3 & 1.5 \\
\hline $\mathrm{HM}[\mathrm{f}]$ & 12.1 & 478.2 & 203.8 & 7.2 & 1.5 \\
\hline $\mathrm{HM}[\mathrm{g}]$ & 12.8 & 550.6 & 229.4 & 5.3 & 0.95 \\
\hline $\mathrm{HM}[\mathrm{h}]$ & 13.3 & 501.8 & 204.4 & 5.4 & 1.1 \\
\hline
\end{tabular}

a): (External surface area/Surface area) $\times 100$

Table 2 Dealumination of $\mathrm{H}$-mordenites

\begin{tabular}{|c|c|c|c|c|c|c|}
\hline \multirow[b]{2}{*}{ Sample } & \multicolumn{2}{|c|}{ Steaming } & \multicolumn{3}{|c|}{ Acid treatment } & \multirow[b]{2}{*}{$\mathrm{SiO}_{2} / \mathrm{Al}_{2} \mathrm{O}_{3}{ }^{\mathrm{a})}$} \\
\hline & $\begin{array}{c}\text { Temperature } \\
\left({ }^{\circ} \mathrm{C}\right)\end{array}$ & $\begin{array}{l}\text { Time } \\
\text { (h) }\end{array}$ & Acid & $\begin{array}{c}\text { Temperature } \\
\left({ }^{\circ} \mathrm{C}\right)\end{array}$ & $\begin{array}{l}\text { Time } \\
\text { (h) }\end{array}$ & \\
\hline \multirow[t]{7}{*}{$\mathrm{HM}[\mathrm{a}]$} & - & - & - & - & - & 18.7 \\
\hline & 600 & 24 & $1 N \mathrm{HCl}$ & 80 & 24 & 37.7 \\
\hline & 600 & 24 & $2 \mathrm{~N} \mathrm{HCl}$ & 80 & 24 & 43.8 \\
\hline & 600 & 24 & $3 \mathrm{~N} \mathrm{HCl}$ & 80 & 24 & 54.6 \\
\hline & 600 & 24 & $6 \mathrm{~N} \mathrm{HCl}$ & 80 & 24 & 124 \\
\hline & 600 & 24 & $8 \mathrm{~N} \mathrm{HCl}$ & 80 & 24 & 230 \\
\hline & - & - & $12 \mathrm{~N} \mathrm{HCl}$ & 80 & 24 & 427 \\
\hline \multirow[t]{8}{*}{$\mathrm{HM}[\mathrm{b}]$} & - & - & - & - & - & 15.7 \\
\hline & 600 & 24 & $1 N \mathrm{HCl}$ & 80 & 24 & 21.7 \\
\hline & 600 & 24 & $4 \mathrm{~N} \mathrm{HCl}$ & 80 & 24 & 34.5 \\
\hline & 600 & 24 & $12 N \mathrm{HCl}$ & 80 & 24 & 55.5 \\
\hline & 600 & 24 & $8 N \mathrm{HCl}$ & 80 & 24 & 90.6 \\
\hline & 600 & 24 & $12 N \mathrm{HCl}$ & 80 & 24 & 130 \\
\hline & 600 & 24 & $16 \mathrm{NHNO}_{3}$ & 80 & 24 & 195 \\
\hline & 600 & 24 & $16 \mathrm{~N} \mathrm{HNO}_{3}$ & 80 & 24 & 347 \\
\hline
\end{tabular}

a) Determined by ICP-AES analysis

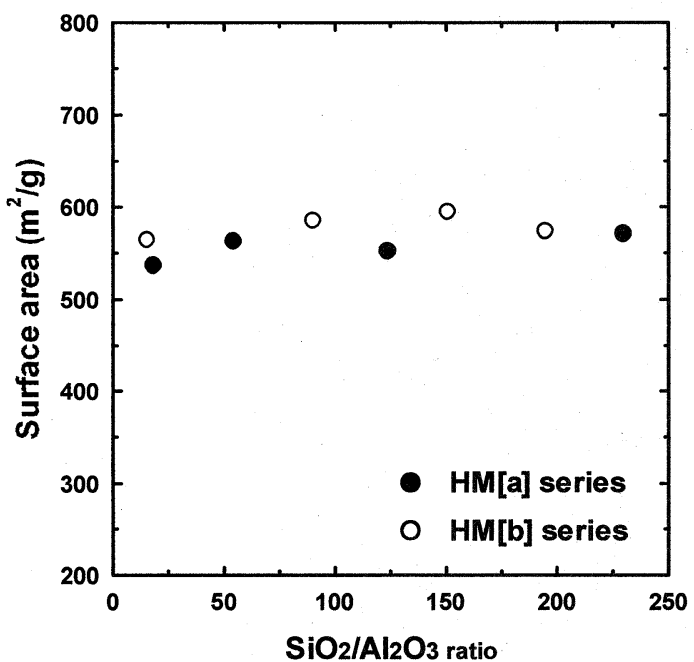

Fig. 3 Effects of the dealumination of $\mathrm{H}$-mordenites on surface area

\subsection{The isopropylation over dealuminated $\mathrm{H}$ - mordenites}

Fig. 4 shows effects of reaction temperature on the isopropylation of $\mathrm{BP}$ over dealuminated $\mathrm{H}$-mordenite $\mathrm{HM}$ (203). The conversion of BP increased with the temperature, and reached $100 \%$ at $300{ }^{\circ} \mathrm{C}$ under our conditions. Shape-selective formation of $4,4^{\prime}$-DIPB was observed at moderate temperature as $250{ }^{\circ} \mathrm{C}$. However, the increase of temperature accompanied the decrease of the selectivity for 4,4' -DIPB with the increase for 3,4' -DIPB. The yield of $4,4^{\prime}$-DIPB reached maximum at $275{ }^{\circ} \mathrm{C}$, and decreased at higher temperatures. On the other hand, the selectivity in encapsulated products of used catalysts was higher than $75-80 \%$ at every temperature. These results show that shape selective formation of 4,4' -DIPB occurred inside the pores by restricted transition state mechanism. The decrease of the selectivity for 4,4' -DIPB does not occur inside pores, but it occurs on the external surface by the isomerization of 4,4' -DIPB to thermodynamically stable isomers, $3,4^{\prime}$ - and 


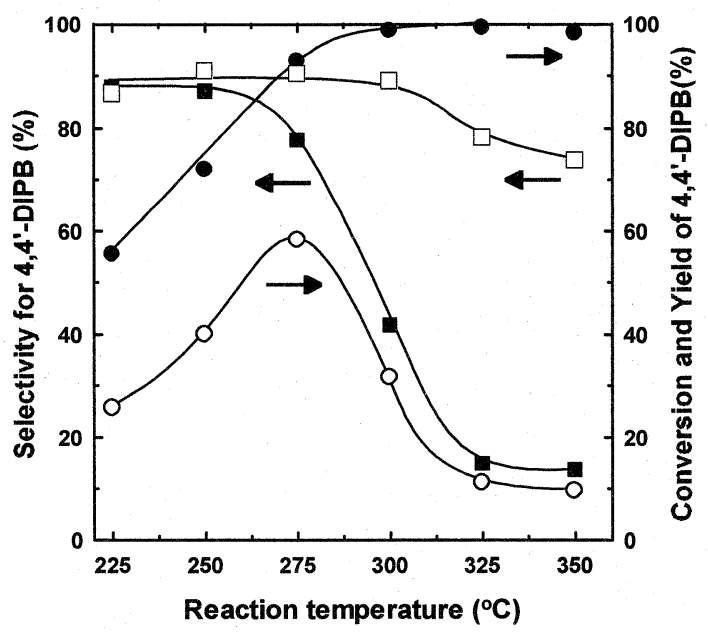

Fig. 4 Effects of reaction temperature on the isopropylation of BP. Reaction conditions: BP, $200 \mathrm{mmol}$; catalyst, $\mathrm{HM}$ (203), $1.0 \mathrm{~g}$; propylene pressure, $0.8 \mathrm{MPa}$; period, $4 \mathrm{~h}$. Symbols: , 4,4' -DIPB in bulk product; $\square, 4,4^{\prime}$-DIPB in encapsulated product; $\bigcirc$, yield of 4,4' -DIPB; Conversion.

3,3' -DIPBs. External acid sites participates in the catalysis such as the isomerization and non-selective alkylation at higher temperatures although they are not active at low to moderate temperatures.

\subsection{The influences of external surface area of $\mathrm{H}$ - mordenites on the isopropylation}

We examined the isopropylation of BP to discuss the role of external acid sites of HMs with wide range of external surface and total areas.

Fig. 5 shows the influence of external surface area of HMs on the isopropylation of BP. There are large differences of the external surface ranged $5.3-25.3 \mathrm{~m}^{2} / \mathrm{g}$ although BET surface areas were ranged within 1.5 times for the smallest sample. From these considerations, we studied the

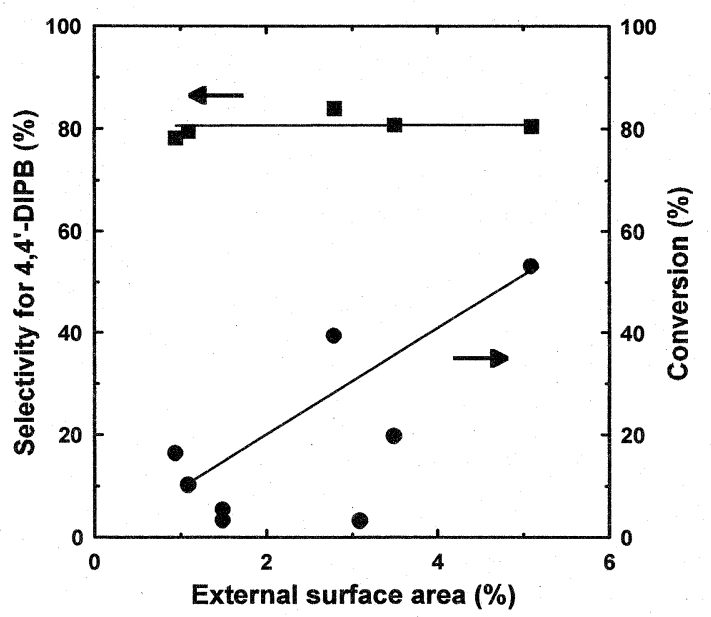

Fig. 5 Effects of external surface area on the isopropylation of BP. Reaction conditions: BP, $100 \mathrm{mmol}$; $\mathrm{H}$-mordenite: $\mathrm{HM}[\mathrm{a}]$ - HM[h], $0.5 \mathrm{~g}$; temperature, $250{ }^{\circ} \mathrm{C}$; propylene pressure, $0.8 \mathrm{MPa}$; period, $4 \mathrm{~h}$ influences of external surface area on the isopropylation of BP because the number of external acid sites is correlated with external surface area. The selectivity for 4,4' DIPB was as high as $80 \%$ for all HMs although catalytic activity was scattered. These results show that the selectivity is not correlated to the difference of external surface area and number of acid sites, and that the shape-selective catalysis inside the pores is due to selective formation of 4,4' -DIPB as discussed in previous papers ${ }^{1) ~ 6)}$. However, catalytic activities were not necessarily correlated for external surface area, although they increased roughly with the increase of external surface area. The scatter of catalytic activity is possibly due to the coke-deposition on HMs, especially, at the pore mouth and to resulting in the decrease of active acid sites. The coke-formation occurred rapidly just after the reaction started, especially for HM with low $\mathrm{SiO}_{2} / \mathrm{Al}_{2} \mathrm{O}_{3}$ ratio as reported previously ${ }^{2)}$ ). HMs with the low surface area rapidly choke the pore, and lose the catalytic activity because the coke-formation decreases the diffusion of substrate and products. The degree of loss of catalytic activity depends on the properties of the samples, such as acid density and distribution. Further investigation is necessary for clear description for the relations of catalytic activity and external acid sites.

\subsection{Effects of dealumination of $\mathrm{H}$-mordenites with dif- ferent particle sizes on the isopropylation}

The dealuminated $\mathrm{H}$-mordenites were prepared from two series of HMs, $\mathrm{HM}[\mathrm{a}]\left(\mathrm{SiO}_{2} / \mathrm{Al}_{2} \mathrm{O}_{3}=18.7\right.$; average particle size: $1.0 \mu \mathrm{m}$; external surface area: $\left.25.3 \mathrm{~g} / \mathrm{cm}^{2}\right)$ and $\mathrm{HM}[\mathrm{b}]$ $\left(\mathrm{SiO}_{2} / \mathrm{Al}_{2} \mathrm{O}_{3}=15.7\right.$; average particle size: $2.5 \mu \mathrm{m}$; external surface area $17.2 \mathrm{~g} / \mathrm{cm}^{2}$ ). HMs with $\mathrm{SiO}_{2} / \mathrm{Al}_{2} \mathrm{O}_{3}$ ratio in the range of 15-400 were obtained by the dealumination. Their surface areas were in almost the same level. It is considered that the dealumination occurs almost uniformly from external and interanl acid sites ${ }^{2}$. The selectivity for 4,4' DIPB in the isopropylation of BP was plotted as high as 80$90 \%$ on identical line for all HMs in both series as shown in Fig. 6 (a). These results show that there is no differences in the selectivity for 4,4' -DIPB for dealuminated HMs in both series although the acid density of external acid sites should be changed in large extents by the dealumination.

Fig. 6 (b) shows the catalytic activity of BP for the isopropylation over dealuminated HMs in two series, HM [a] and HM[b]. Catalytic activities of HMs were scattered in wide range; however, there are some tendencies by the increase of $\mathrm{SiO}_{2} / \mathrm{Al}_{2} \mathrm{O}_{3}$ ratio. Catalytic activity increased in the region of $\mathrm{SiO}_{2} / \mathrm{Al}_{2} \mathrm{O}_{3}$ ratio below 200 in both series, and further increase of the ratio resulted in the decrease of the conversion. The increase of activity in lower region is due 

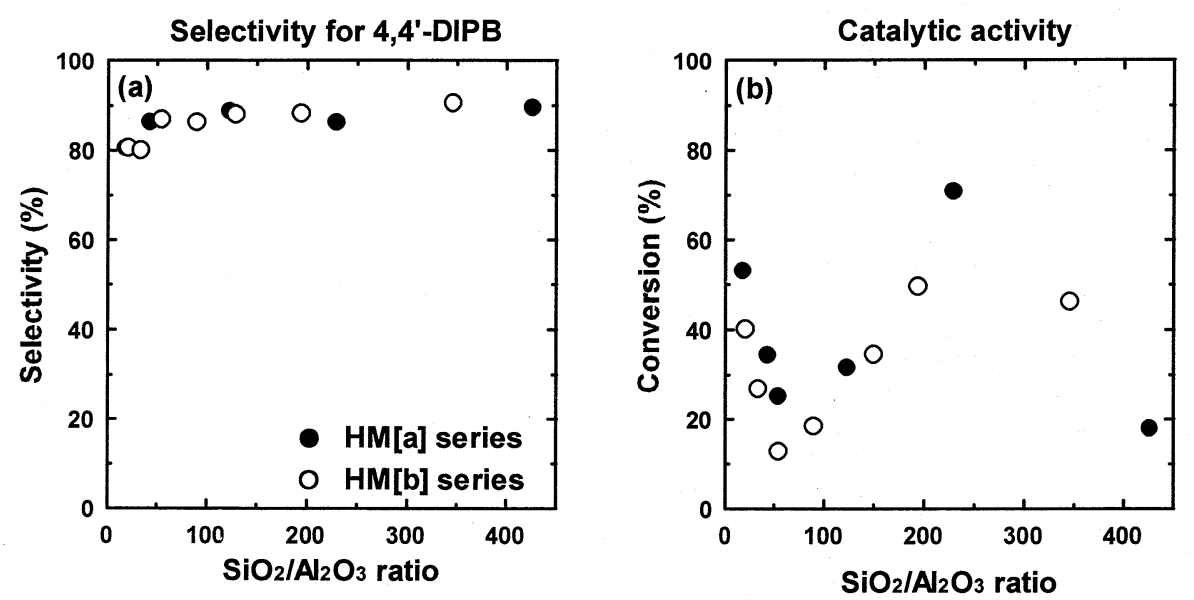

Fig. 6 Effects of $\mathrm{SiO}_{2} / \mathrm{Al}_{2} \mathrm{O}_{3}$ ratio of $\mathrm{H}$-mordenites on the selectivity (a) and catalytic activity (b) in the isopropylation of BP. Reaction conditions: BP, $200 \mathrm{ml}$; dealuminated sample $\mathrm{HM}[\mathrm{a}]$ or $\mathrm{HM}[\mathrm{b}], 1 \mathrm{~g}$; temperature, $250{ }^{\circ} \mathrm{C}$, propylene pressure, $0.8 \mathrm{MPa}$; period, $4 \mathrm{~h}$.

to the decrease of choke of the pores by the coke-deposition, and the decrease of activity at higher region is due to the decrease of catalytic active acidic sites by the deep dealumination. Dealuminated HM[a] with smaller particle size has generally higher activity than $\mathrm{HM}[\mathrm{b}]$; however, there is not significant difference in the activity between two series.

These results show that shape-selective formation of 4,4' DIPB was observed for all HMs in the isopropylation of BP although catalytic activity was changed by the dealumination of HMs with different particle size. It is concluded from these results that shape-selective isopropylation of BP occurred inside pores, and that acid sites on external surface did not play important role at the catalysis at moderate conditions.

Many researchers have interested in the influence of external acid sites, especially, their deactivation in shapeselective catalysis using zeolites ${ }^{14) \sim 21}$. We previously described the isomerization of 4,4' -DIPB at higher temperatures as shown in Fig. 4 was prevented by the modification of external acid sites with ceria ${ }^{17)}$ and silica ${ }^{18)}$. Kikuchi and his co-workers found that phosphorus oxide modification of HM deactivated external acid sites in the isopropylation of $\mathrm{BP}^{19}$. Yashima and his co-workers found that the addition of 2,4-dimethylqunoline (2,4-DMQ) enhanced the formation of 2,6-dimethylnaphthalene in the methylation of 2-methylnaphthalene over ZSM-5 zeolites: non-selective formation of DMN isomers at external acid sites was prevented by the deactivation by $2,4-\mathrm{DMQ}^{20}$. They also reported the isomerization of $p$-diethylbenzene at the external acid sites in the ethylation of ethylbenzene with ethanol over ZSM-5 zeolites; however, the isomerization was prevented by the addition of $2,4-\mathrm{DMQ}^{20)}$.

\section{Conclusion}

The isopropylation of BP was studied over two types of HM to elucidate the roles of external acid sites in shapeselective catalysis. First, we examined the isopropylation of BP over the several HMs with wide range of external surface area from $5.3 \mathrm{~m}^{2} / \mathrm{g}$ to $25.3 \mathrm{~m}^{2} / \mathrm{g}\left(\mathrm{SiO}_{2} / \mathrm{Al}_{2} \mathrm{O}_{3}=13.3-\right.$ 18.7). The selectivity for $4,4^{\prime}$-DIPB was in the similar level over all HMs. These results show that selective formation of 4,4' -DIPB occurred inside pores for all HMs with wide range of surface area. Because the number of external acid sites should be proportional to surface area, we can conclude that external acid sites do not play an important role for the catalysis. However, the activity was varied by the surface area, and roughly proportional to external surface area. We have no definitive description for influences of external acid sites on catalytic activity; however, HMs, especially, with low $\mathrm{SiO}_{2} / \mathrm{Al}_{2} \mathrm{O}_{3}$ ratio, are sometimes deactivated by coke-deposition, which occurs easily in the early stage of the reaction on acid sites at the pore mouth.

Secondly, we examined the dealumination of two series of HMs with different particle size, $\mathrm{HM}[\mathrm{a}]\left(\mathrm{SiO}_{2} / \mathrm{Al}_{2} \mathrm{O}_{3}=18.7\right.$; average particle size: $1.0 \mu \mathrm{m}$; external surface area: 25.1 $\left.\mathrm{g} / \mathrm{cm}^{2}\right)$ and $\mathrm{HM}[\mathrm{b}]\left(\mathrm{SiO}_{2} / \mathrm{Al}_{2} \mathrm{O}_{3}=15.7\right.$; average particle size: $2.5 \mu \mathrm{m}$; external surface area $\left.17.2 \mathrm{~g} / \mathrm{cm}^{2}\right)$. HMs with $\mathrm{SiO}_{2} /$ $\mathrm{Al}_{2} \mathrm{O}_{3}$ ratio in the range of $15-400$ were obtained by the dealumination and their surface areas were in the similar level. The selectivity for 4,4' -DIPB for the isopropylaiton of BP was in the similar level for both series of all HMs although the numbers of external acid sites should be changed significantly. On the other hand, catalytic activity was varied with $\mathrm{SiO}_{2} / \mathrm{Al}_{2} \mathrm{O}_{3}$ ratio. One possible explanation of the changes of catalytic activity is due to the decrease of coke-deposition at lower region of $\mathrm{SiO}_{2} / \mathrm{Al}_{2} \mathrm{O}_{3}$ ratio, but to the decrease of acid sites at the higher ratio. 
These results from two types of HMs on the isopropylation of BP show that selective formation of 4,4' DIPB occurred inside their pores of HMs with different density of external acid sites. External acid sites did not play an important role on the shape-selectivity at moderate temperature such as $250{ }^{\circ} \mathrm{C}$; however, catalytic activities for the isopropylation were influenced by external surface area.

Further aspects of the role of external acid sites on shapeselective catalysis are under investigation.

\section{References}

1) Y. Sugi and Y. Kubota, in Catalysis, Vol. 13, a Specialist Periodical Report, edited by J. J. Spivey (Royal Soc. Chem., London,1997) Chapter 3, pp.55-84

2) Y. Sugi, T. Matsuzaki, T. Tokoro, T. Hanaoka, T. Hanaoka, X. Xu, and G. Takeuchi, J. Jpn. Petrol. Inst., 37, 376 (1994)

3) Y. Sugi, X. Xu, T. Matsuzaki, T. Hanaoka, Y. Kubota, J. -H. Kim, M. Matsumoto, K. Nakajima, and A. Igarashi, Catal. Today, 31, 3 (1996)

4) S. Tawada, Y. Kubota, Y. Sugi, T. Hanaoka, and T. Matsuzaki Catal. Lett., 57, 217 (1999)

5) Y. Sugi, S. Tawada, T. Sugimura, Y. Kubota, T. Hanaoka, T. Matsuzaki, K. Nakajima, and K. Kunimori Appl. Catal. A: General, 189, 251 (1999)

6) S. Tawada, Y. Kubota, Y. Sugi, Y. Kiyozumi, and F. Mizukami, Catal. Catal., 42, 378 (2000)

7) O. J. Whittemore, Am. Mineral. 57, 1146 (1972)

8) G. J. Kim and W. S. Ahn, Zeolites 11, 745 (1991)
9) S. Ueda, T. Fukushima, and M. Koizumi, Am. Mineral., 65, $1012(1980)$

10) S. Ueda, T. Fukushima, M. Koizumi, J. Clay Sci. Jpn., 22, $18(1982)$

11) Y. Kiyozumi, H. Kato, M. Hashimoto, F. Mizukami, and A. Iwasaki, Proc. Silica 98, Sep. 1-4, 1998, pp.485-488

12) S. Mintova and V. Valtchev, Micropor. Mesopor. Mater., $55,171(2002)$

13) B. C. Lippens and J. H. de Boer, J. Catal., 4, 319 (1965)

14) M. Niwa, T. Kunieda, and J. -H. Kim, in "Shape-Selective Catalysis. Chemical Synthesis and Hydrocarbon Processing”, ACS Symp. Ser. 738, pp.181-187 (1999)

15) M. Niwa, K. Kato, T. Hattori, and Y. Murakami, J. Phys. Chem., 90, 6233 (1986)

16) J. -H. Kim, Y. Sugi, T. Matsuzaki, T. Hanaoka, Y. Kubota, X. Tu, M. Matsumoto, A. Kato, G. Seo, and C. Pak, Appl. Catal., A:General 131, 15 (1995)

17) S. Tawada, Y. Sugi, Y. Kubota, Y. Imada, T. Hanaoka, T. Matsuzaki, K. Nakajima, K. Kunimori, and J.H. Kim, Catal. Today, 60, 243 (2000)

18) M. Hayashi, S. Tawada, Y. Kubota, Y. Sugi, and J.-H. Kim, React. Kinet. Catal. Lett. 83, 329 (2004)

19) E. Kikuchi, K. Sawada, M. Maeda, and T. Matsuda, Stud. Surf. Sci. Catal., 90, 391 (1994)

20) T. Komatsu, J.H. Kim, and T. Yashima, in "Shape-Selective Catalysis. Chemical Synthesis and Hydrocarbon Processing” , ACS Symp. Ser. 738, pp.162-180 (1999)

21) Y. Sugi, Y. Kubota, N. Sugiyama, M. Hayashi, and J.-H. Kim, Catalysts and Catalysis, 40, 462 (2002) 